\title{
VHFプラズマ励起スラブ型炭酸ガスレーザーの短パルス化
}

\author{
森 啓*, 橋西 良延*,†, 鈴木 薰**, 中田 順治** \\ *日本大学大学院 理工学研究科電気工学専攻 (₹101-8308 東京都千代田区神田駿河台1-8-14) \\ **日本大学 理工学部電気工学科 ( $\bar{\top} 101-8308$ 東京都千代田区神田駿河台1-8-14)
}

\section{A Method to Produce Short Pulse on a VHF-Plasma Excitation Slab-Type $\mathrm{CO}_{2}$ Laser}

\author{
Akira MORI,* Yoshinobu HASHINISHI, ${ }^{* \dagger}{ }^{\dagger}$ Kaoru SUZUKI, ${ }^{* *}$ and Junji NAKATA** \\ * Electrical Engineering Major, Graduate School of Science and Technology, Nihon University \\ 1-8-14 Kanda-Surugadai, Chiyoda-ku, Tokyo 101-8308 \\ ** Department of Electrical Engineering, College of Science and Technology, Nihon University \\ 1-8-14 Kanda-Surugadai, Chiyoda-ku, Tokyo 101-8308
}

(Received February 22, 1999)

\begin{abstract}
We propose a novel method for producing a short pulse from a VHF-discharge-excitation slab-type $\mathrm{CO}_{2}$ laser using a halved confocal of an unstable concave and convex resonator. This method utilizes a full reflection concave mirror with a function of variable curvature, which can be controlled using a piezo electric device (PZT). Generally, slab-type lasers are modulated directly by varying pulse voltage; however, there is a fluctuation of plasma at the transition of the $\mathrm{kHz}$ pulsation. Consequently, the repetitive frequency is less than 10 $\mathrm{kHz}$. On the other hand, the pulse oscillation with our method has a short pulse width of $300 \mathrm{~ns}$ and a maximum repetitive frequency of about $58 \mathrm{kHz}$. The peak power at the pulse oscillation is about 12 times as high as that of the $\mathrm{CW}$ oscillation.
\end{abstract}

Key Words: Slab-type $\mathrm{CO}_{2}$ laser, Cavity dumping, Short pulse, Unstable resonator

\section{1.まえがき}

炭酸ガスレーザーは発振効率が高く高出力を得られる こと,及び各種材料での吸収率が大きいことから加工を中 心とした産業に広く用いられている。このレーザーを加 工に用いるに当たり, 加工部周辺域での変形や変質といっ た熱的影響を防ぎ加工精度を向上させる必要から加工用 光源であるレーザー光の短パルス化が要求されている. また, コスト面からレーザー装置の小型化, 高出力化, 高効 率化, 及びパルス繰り返し周波数の増大が要求されてい る1). そこで, 著者らは比較的発振効率が高く, 小型の装置 でも高出力が得られるスラブ型の炭酸ガスレーザー2-7)に 着目し,このレーザー出力を短パルス化することを目的に 研究を行っている.

このレーザーは幅広のレーザー媒質を有し, 効率等の面 から不安定共振器が用いられている8). パルス化の方法と しては, 一般に電源変調法が用いられているが, アフター グローの影響等によるプラズマの消滅時間による制限の ために繰り返し速度は $10 \mathrm{kHz}$ 程度となり, 高い繰り返し周 波数で短パルス発振を行う方法が要求されている。そこ
で,アフターグローの影響を防ぐため, 入力電力を変化さ せずレーザー媒質を一定の状態にし, 光共振器の形態を変 化させるキャビティダンピング法9)を適用することを検討 した.

この方法を用いることにより,パルス幅(半值幅)は最短 で約300nsec, 繰り返し周波数は $58 \mathrm{kHz}$, 波高值は最大で連 続発振時の約12倍の出力を持つパルス発振を行うことに 成功した。 また,レーザーは不安定共振器を構成する全反 射ミラーの形状を変化させるかどうかで容易にパルス発 振にするか, 連続発振にするかを切り替えられる特徵も有 している.

本論では, このパルス化方法の検討及び実際にこの方法 によりパルス化を行った測定結果とレート方程式を用い た数値解析結果を報告する.

\section{2. 実験装置と方法}

著者等が考案したキャビティダンピング法の概略を Fig.1に示す. Fig.1 (a) は一次元不安定共振器の概略であ る.レーザー光は共振器を構成する出力側ミラー(凸面鏡)

\footnotetext{
†現在の所属：凸版印刷(株)（†101-0024 東京都千代田区神田和泉町1）

$\dagger$ Present affiliation: Toppan corporation, 1 Kanda-Izumicho, Chiyoda-ku, Tokyo 101-0024
} 


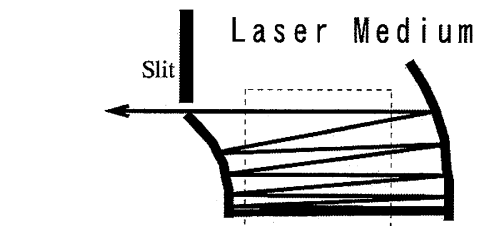

Full Reflection Full Reflection Mirror Mirror

(Out Side Mirror) (End Mirror or

Variable Curvature

Mirror)

(a)

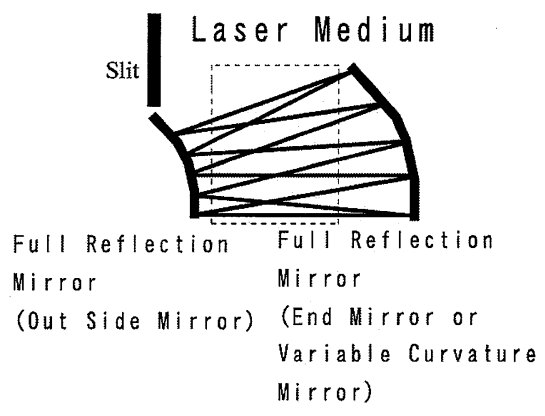

(b)

Fig.1 (a) Principle of the cavity dumping method (Output Condition). (b) Principle of the cavity dumping method (Amplification Condition).

とエンドミラー(凹面鏡)の間を少しずつ光軸をずらしなが ら反射・往復し, 増幅され, 最終的に出力側ミラーの一端 より共振器外に出力される (出力状態). ここでエンドミ ラーを曲率可変構造とし, その曲率半径を変化させると, 同 一の共振器においてFig.1 (b)のようにレーザー光が共振器 内に閉じこめられ, 共振器外に出力されない状態(増幅状 態)を作ることが可能になる．この状態においてレーザー 光は共振器内に閉じこめられ, 増幅し強められるだけとな る.エンドミラーの曲率を超音波振動子などにより高速 で変化させ, 増幅状態と出力状態を周期的に切り換えれ ば, 増幅状態で共振器内に閉じこめられたレーザー光を出 力状態になった瞬間にパルスとして出力させることがで きる。

実験装置の概略図をFig.2に示す。

スラブレーザーは, 長さ $430 \mathrm{~mm} \times$ 幅 $35 \mathrm{~mm}$ の銅製電極 2 個 を間隔 $2 \mathrm{~mm}$ 一定になるように対向させたものである。ス ペーサはパイレックスガラスを用いた。レーザー媒質は $\mathrm{CO}_{2}: \mathrm{N}_{2}: \mathrm{He}=1: 2: 7$ の混合ガスを管内気圧 $25 \mathrm{Torr}$ 一定に なるようにフローさせ, $100 \mathrm{MHz}$ の高周波電源により放電 電力 $300 W 一$ 定で放電させている.

共振器は出力側ミラーとして曲率半径 $4.4 \mathrm{~m}$, 長さ $25 \mathrm{~mm}$ の全反射ミラー(三重光学製, $\mathrm{BeCu}$ 表面に金蒸着)を, エン ドミラーは曲率半径を可変できる構造とした全反射ミ

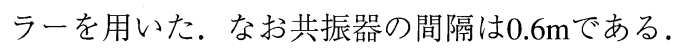

エンドミラーの構造をFig.3に示す。ミラーは長さ $60 \mathrm{~mm}$ $\times$ 幅 $30 \mathrm{~mm}$ の金属板表面をミラー加工したものである。取 り付け部より $25 \mathrm{~mm}$ の位置 (以下変位供給点と呼ぶ)におい て後方よりスライドステージ(シグマ光機製：MF-50) と圧

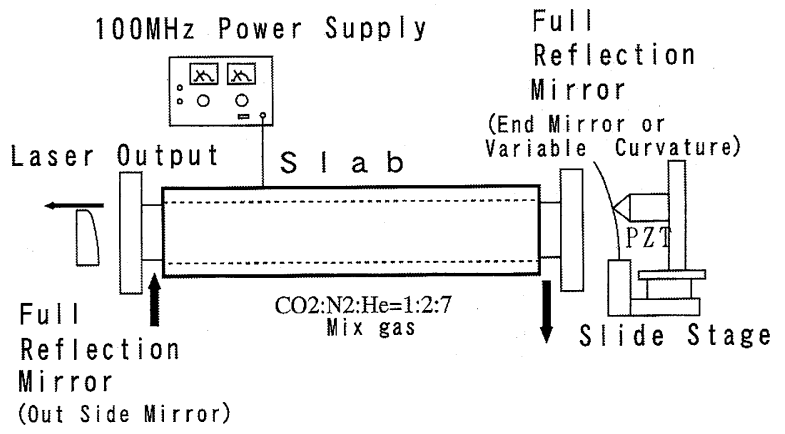

Fig.2 Schematic diagram of experimental apparatus.

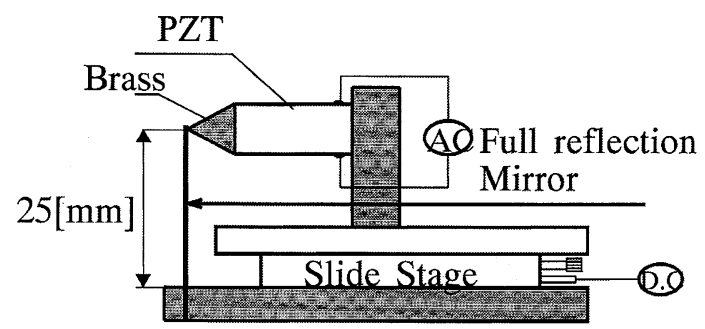

Fig.3 Configuration of the end mirror (Variable curvature).

電素子 $(\mathrm{PZT}$, トーキン製, 共振周波数 $58 \mathrm{kHz})$ により変位を 加えることでミラーに曲率を与える構造とした，スライ ドステージでエンドミラーに定常的な曲率を与えて連続 発振を行わせ,その状態から圧電素子に交流電圧を印加す ることで高速な曲率の変化を与えパルス化を行った。

パルス発振時のレーザー出力はCdTe製Photo Detector (Rabimex製, R005-2, 応答速度1ns) とデジタルストレージ スコープ(岩崎通信機製, DS-8606), CW発振時の出力は LASER POWER METER(Ofiele製, PWX-30)で測定した。

尚, 圧電素子の振動量は超精密非接触変位計 (Optmetric OM-10)で測定した值を用いた。尚, 共振周波数の $58 \mathrm{kHz}$

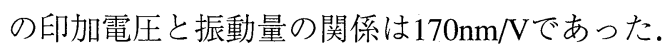

\section{3. レート方程式の適用について}

炭酸ガスレーザーにおいてその発振過程をレート方程 式により解析する際, Fig.4に示す三準位モデルがよく用い られる。このモデルより得られるレート方程式は以下の ようになる。

$\frac{d n}{d t}=B n\left(M_{1}-M_{2}\right)+A M_{1}-k n$

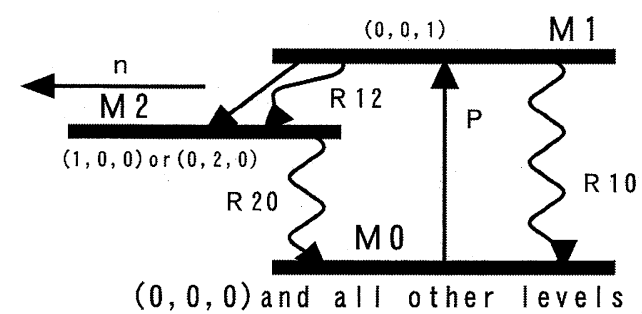

Fig.4 The model of energy level for the $\mathrm{CO}_{2}$ laser (Threelevel laser) oscillator system. 
$\frac{d M_{0}}{d t}=R_{10} M_{1}+R_{20} M_{2}-\left(P+R_{02}\right) M_{0}$

$\frac{d M_{1}}{d t}=-B n\left(M_{1}-M_{2}\right)+P M_{0}-\left(R_{10}+R_{12}\right) M_{1}+R_{21} M_{2}$

$$
\frac{d M_{2}}{d t}=B n\left(M_{1}-M_{2}\right)+R_{12} M_{1}+R_{02} M_{0}-\left(R_{20}+R_{21}\right) M_{2}
$$

但し, $n$ : 光子密度, $M_{i}$ : 各エネルギー準位にある分子密 度 $(i=0,1,2), k$ : 管内損失率, $P$ : ポンピング確率, $A$ : 自 然放出係数, $B:$ 誘導放出係数, $R_{i j}: i$ 潐位より $j$ 準位への遷 移率である。ここで低いエネルギー準位から高いエネル ギー準位への遷移率はその逆過程に比べ十分に小さいと して0Hzにした. 自然放出係数 $A$ も誘導放出係数 $B$ よりも十

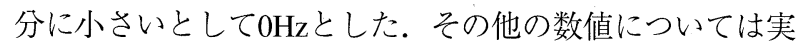
験及び成書 ${ }^{10,11)}$ を参考に求めた。尚, $M$ は炭酸ガス分子の 全分子密度 $\left(=M_{0}+M_{1}+M_{2}\right)$ である.

このパルス化法によるパルス発振の動作を解析する際 は, 取り出し率の変化による結合損失がレーザー共振器の 形状変化により変化するものとして計算した。

\section{4. 実験結果と検討}

4.1 ミラーのたわみ方とスライドステージによる曲率 変化について

装置を構成するにあたり，まず円弧状に連続してたわむ エンドミラーの材料を検討することとした.

Fig.5はエンドミラーの材質によるたわみ方の変化を， He-Neレーザーを用いた光線追跡法により求めた結果であ

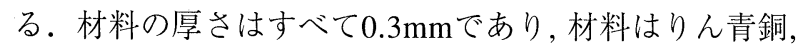
銅, 真鍮を用いた。測定は変位供給点で計算上最も出力の 得られる曲率半径 $5.6 \mathrm{~m}$ となるようにして行った。また, 図 中の曲線は曲率半径 $5.6 \mathrm{~m}$ の円弧を示す。これによると,こ の材質の中ではりん青銅が最も円弧に近い形で変形する ことが判明した。

Fig.6はりん青銅の厚さの違いによるエンドミラーのた わみ方の変化を, 同様の方法と条件で求めた結果である. 厚さを $0.1 \mathrm{~mm}$ から $0.5 \mathrm{~mm}$ まで変化させ測定した結果, 厚さ $0.3 \mathrm{~mm}$ のもの゙最も円弧に近い形で変形することが判明し た. 以後エンドミラーには厚さ $0.3 \mathrm{~mm} の り ん$ 青銅製を用い ることとした.

Table 1 Parameter values used in the numerical calculation.

\begin{tabular}{lcc}
\hline \hline $\begin{array}{l}\text { Pumping rate } \\
\text { Rate of the vibration relaxation } \\
(0,0,1)-(0,0,0)\end{array}$ & $R_{10}$ & $200 \mathrm{~Hz}$ \\
$\begin{array}{l}\text { Rate of the vibration relaxation } \\
(0,0,1)-(1,0,0) \text { or }(0,2,0)\end{array}$ & $R_{12}$ & $50 \mathrm{Hzz}$ \\
$\begin{array}{l}\text { Rate of the vibration relaxation } \\
(1,0,0) \text { or }(0,2,0)-(0,0,0)\end{array}$ & $R_{20}$ & $870 \mathrm{kHz}$ \\
$\begin{array}{l}\text { Confident of stimulated emis- } \\
\text { sion }(B) \times \text { Total molecule den- } \\
\text { sity }(M)\end{array}$ & $B \times M$ & $4.3 \mathrm{GHz}$ \\
Cavity-loss rate & $k$ & Varied \\
\hline \hline
\end{tabular}

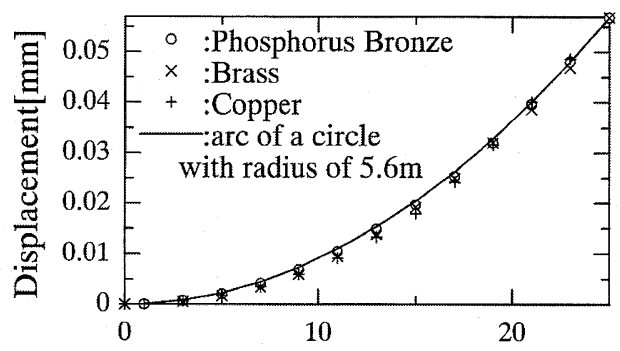

Distance from fixed point [mm]

Fig.5 Dependence of the displacement on the end mirror of materials. Experimental results are indicated with $\bigcirc, x,+$. The solid line is the calculated arc of a circle with a radius of 5.6 meter.

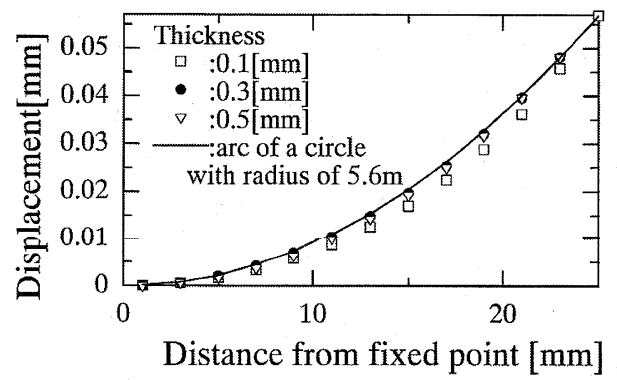

Fig.6 Dependence of the displacement on the end mirror of thickness. Experimental results are indicated with $\square, \nabla$. The solid line is the calculated arc of a circle with a radius of 5.6 meter.

エンドミラーの曲率半径変化の連続性を調べるために スライドステージ駆動直流電圧を変化し, 曲率半径の変化 を調べた結果をFig.7に示す。スライドステージにより曲 率半径を $10 \mathrm{~m} \sim 3 \mathrm{~m}$ の間で調整でき, かつ曲率半径 $5.6 \mathrm{~m}$ 付近 において印加電圧に対し曲率半径が直線的に変化するこ とが確認された。

4.2 不安定共振器における連続発振時の出力観測とシ

$$
\text { ミュレーション }
$$

Fig.8の黒点は前項のエンドミラーを用いて実際に不安 定共振器を形成し連続発振させ, エンドミラーの曲率半径 に対するレーザー出力特性を測定した結果である.レー ザー出力は曲率半径 $5.6 \mathrm{~m}$ で最大となり, その前後で急激に 減少している．尚, レーザー発振は曲率半径が $3.5 \mathrm{~m} \sim 6.4 \mathrm{~m}$ の領域で確認された。このことから, 曲率半径 $5.6 \mathrm{~m}$ 付近が

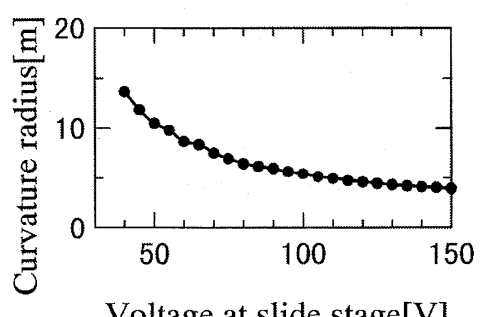

Fig.7 Dependence of the curvature radius at the end mirror on voltage at slide stage. 


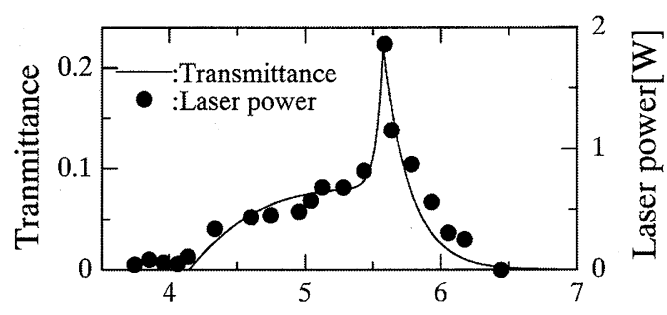

Curvature radius $[\mathrm{m}]$

Fig.8 Dependence of the laser power (represented by dots) and the Transmittance (represented by solid line) on the curvature radius.

出力状態 (Fig.1 (a))に, 曲率半径が5.6mより小さくレー ザー出力の小さな領域が増幅状態(Fig.1 (b))にあたると考 えられる。

実際の取り出し率は回折等により変化し且つ,レーザー 取り出し口に設置したSlitの影響により取り出し口の大き さが制限され，出口より拡散する成分が損失となるので極 值が存在する。よって測定結果よりこの不安定共振器の 出力の取り出し率を近似し, Fig.8の実線に示す。共振器の 形状変化によるパルス化を解析する際においてはこの取 り出し率が変化するものとして計算を行った.

4.3 ミラーのずれがレーザー出力に与える影響について Fig.9はミラーの中心軸のずれがレーザー発振に与える 影響について検討した結果である。ミラーの中心軸を上 下方向にずらすと,レーザー発振の確認された領域及び最 大出力が得られる曲率半径は軸ずれに対応して変化し,か つレーザーの最大出力の值は低下することが判明した。

本パルス化法においては, レーザー出力の変化が大きい 方が短パルスで高波高值を望めると考えられるので軸ず れのないよう注意する必要がある.

\section{4 連続発振時とパルス発振時の出力比較}

今回最も大きい波高值の得られたパルス発振時の波形 (PZT印加周波数58kHz, PZT振動変位量1.0um (peak to peak, 曲率半径の変化に換算して約 $0.1 \mathrm{~m})$ ) とCW出力時をチョッ パでチョッピングし測定した波形の比較をFig.10に示す.

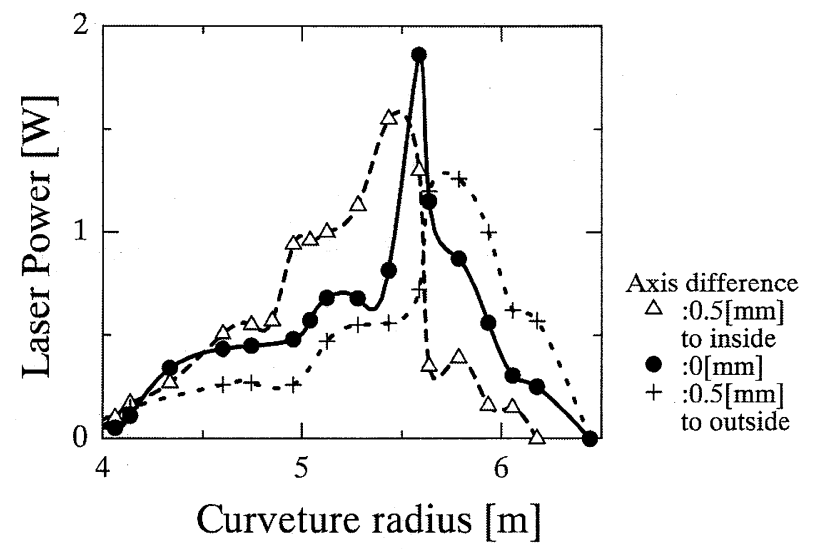

Fig.9 Dependence of the laser power on the axis difference.

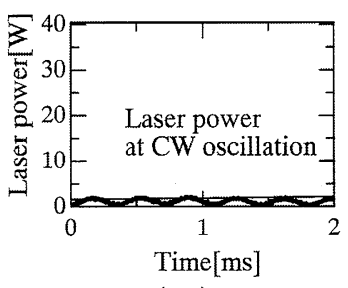

(a)

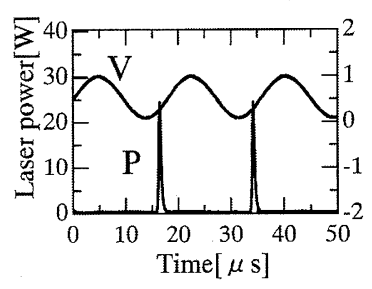

(b)
Fig.10 Comparison between laser power at CW oscillation and at the pulse oscillation. Fig (a) shows the waveforms after chopping at $\mathrm{CW}$ oscillation. Fig (b) shows the waveforms at the pulse oscillation. The waveform of $\mathrm{V}$ is voltage at PZT. The waveform of $\mathrm{P}$ is laser power.

図中のVはPZT印加電圧波形, Pは測定波形である.

PZTの1振動周期に1回鋭いパルス発振が生じていること が確認された。パルス発振時の波高値は最大で連続発振 時の約12倍の大きさである.

\section{5 初期曲率の違いによるパルス出力特性}

Fig.11はエンドミラーにスライドステージによって加え られる初期曲率を変え,パルス波形の形状変化を調べた結 果である. PZT印加電圧の周波数はPZTの共振周波数であ る58kHz, PZTの振動変位量はpeak to peakで1.0umとした。 図中VはPZT印加電圧波形, $\mathrm{P}$ は測定波形, nは三準位レート 方程式を用いた計算結果に扔ける光子密度の波形であ る。また, Bias Pointは各条件に扔ける曲率変化域の中で曲 率半径が最大の点を示す.

測定結果及び計算結果ともにBias Point 5.6mにおいて波 高值が最大でパルス幅が最小になっている。このことか らエンドミラーの曲率半径を曲率半径 $5.6 \mathrm{~m}$ から曲率半径

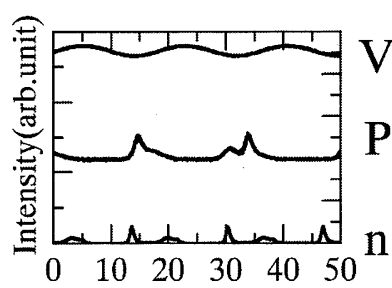

Time $[\mu \mathrm{sec}]$

Bias Point $5.75[\mathrm{~m}]$

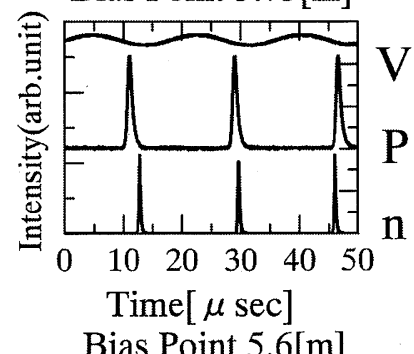

Bias Point 5.6[m]
Vibration displacement of PZT:500[nm] Frequency:58[kHz]

Fig.11 Dependence of pulse wave (observed (V, P) and calculated (n)) on Bias point. The waveform of $n$ is photon density. 
の小さい方に変動させると最も短パルスを得られること が判明した．尚,このときのパルス幅は約300nsecであり， raise timeは240nsec, fall timeは425nsecであった.

この比較結果から我々の行ったキャビティダンプ法に よるパルス化は三準位レート方程式において取り出し率 の変化により解析できることを示唆している.

\section{5. まとめ}

スラブ型炭酸ガスレーザーをパルス化する新しい方法 を実験・計算の両面から検討し以下の結果を得た。

1) 凸面鏡と凹面鏡を対向させた不安定共振器において, 凹 面鏡の曲率半径を制御するキャビティダンピング法に より連続発振スラブ型炭酸ガスレーザーの出力をパル ス化することに成功した.

2)パル，幅は最短で約 $300 \mathrm{~ns}$, 繰り返し周波数は $58 \mathrm{kHz}$, 波 高值は最大で連続発振時の約12倍の出力を持つパルス 発振が得られた。

3) キャビティダンプ法によるパルス化は三準位レート方 程式において取り出し率の変化により解析できること が示唆された。

尚, 本研究においてはキャビティダンピング法を実践す るための条件について研究を行ったが, ミラーを振動させ る条件については更なる検討が必要である。また, 本論で はパルス機構の解析を成書の值を参考とした数值を中心 に数值計算を行ったが, 今後パルス特性やプラズマ特性を 実測しそのデー夕を基にした解析を行う必要があると考 える。

\section{6. 謝 辞}

本研究を行うにあたり御教授, 御指導を賜りました升谷 孝也名誉教授に深甚の謝意を表します。また, 実験に協力 していただいた猪目 孝志, 藤島 剛, 日高 康博, 高久 雅弘, 北林哲, 嘉成 和孝各氏を初めとする放電・レーザー研究 室の方々に深く感謝いたします。

\section{参考文献}

1）浅見 義弘, 稲葉 文男, 犬石 嘉雄, 桜井 健二郎, 菅原 吉彦, 難波 進, 平野順三, 山中 千代衛：レーザ工学 (東京電機大学出版 局, 1983) p.184.

2) 小原 實, 荒井 恒憲, 緑川 克美：レーザ応用工学（コロナ社, 1998) p.4.

3) C. G. Parazzoli and K. Chen: IEEE J. Quantum. Electron QE-22 (1986) 479.

4) W. Schock, B. WalL, K. Wessel, and E. Wildermuth: SPIE 1225 High power gas lasers (1990) 349.

5) 葛本 昌樹：平成八年電気学会全国大会講演論文集（1996） S.4.27-S.4 30 .

6) D. H. Hall and D. R. Hall: IEEE J. Quantum. Electron QE-20 (1989) 509.

7) 西前 順一, 吉沢 憲治：電学論 A 112 (1992) 1.

8) R. Nowack, H. Opower, U. Schaefer, K. Nessed, and T. Hall: SPIE lasers and applications II (1990) 18.

9）レーザー学会編：レーザーハンドブック（オーム社, 1982) p.196, p.362.

10) M. Tachikawa, K. Tanii, M. Kajita, and T. Shimizu: Appl. Phys. B 39 (1986) 83.

11) M. Tachikawa, K. Tanii, M. Kajita, and T. Shimizu: J. Opt. Soc. Am 5 (1988) 24. 